\title{
完全重複腎孟尿管に伴う泌尿器科的諸問題の診断と治療
}

\section{-22 症例の追加と前回報告23症例との比較一}

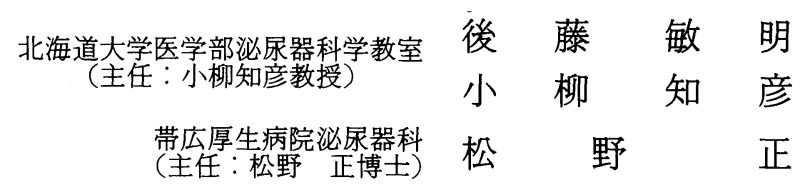

\section{THE DIAGNOSIS AND TREATMENT OF UROLOGICAL PROBLEMS ASSOCIATED WITH COMPLETE DUPLEX SYSTEM:}

Report of Another 22 Cases Compared with 23 Cases which were Reported Previously

\author{
Toshiaki Gotoh and Tomohiko Koyanagi \\ Department of Urology, Hokkaido University School of Medicine \\ (Director: Prof. T. Koyanagi) \\ Tadashi Matsuno \\ Department of Urology, Obihiro Kosei Hospital \\ (Director: Dr. T. Matsuno)
}

Twenty-two cases of complete duplication of urinary tract, experienced from 1977 to 1985, were reviewed. They were subdivided into 3 groups; Group I of 11 cases with ectopic ( 2 exceptions) ureterocele, Group II of 8 cases with reflux and Group III of 3 cases without ureterocele or reflex.

All the patients were female and their mean age was as follows: Group I (8.3 yrs.), Group II (18.4 yrs.) and Group III ( 2.8 yrs.). Their clinical symptoms were urinary tract infection ( 20 cases) followed by incontinence, dysuria and prolapse of ureterocele.

Full utilization of diagnostic modalities such as renoscintigram, voiding cystourethrography (VCU) and endoscopy along with a timely suspect of the duplication was quite important. Renoscintigram was useful to evaluate upper segment function when not visualized on excretory urography. VCU and endoscopy were also useful to know the eversion of the ureterocele and the type of the hiatus. These knowledge was valuable in the management of the ureteral stump. The type of the hiatus was well correlated to the renal function and the incidence of renal dysplasia.

Eighteen patients required some forms of operative treatment. Regarding the operation the significance of not leaving excess ureteral stump was discussed and our method was also described in detail. Though unroofing of the ureterocele was controversial, distal incision of it was also utilized in the diagnosis and treatment, namely to know the type of the hiatus of the non-everting ureterocele, to evaluate the renal function after the relief of obstruction and to make it easier to resect the distal margin of the ureterocele at the time of operation. In some cases it may be the sole treatment for a cure.

\footnotetext{
要旨：1977年から1985年までに経験した完全重複腎孟尿管22例を I 群（尿管瘤）11例，II群（逆流）8 例，III群（その他） 3 例の 3 群に分け検討した。全例女子で平均年齢は各8.3歳，18.4歳，2.8歳で臨床 症状は尿路感染が多く次いで尿失禁，排尿困難，瘤脱などであった．腎シンチ，排尿時膀胼尿道造影， 内視鏡検査が特に大切で IVP 上無機能な腎の真の機能評価, 瘤外翻の有無や尿管裂吵の型決定に有用 で，これらの情報は治療方針決定に必須であった。尿管裂隙の型は腎機能や腎形成異常の頻度とも密接 に関連していた。手術的治療は 18 例に施行, 特に尿管末端の可及的摘出が大切でその術式を紹介した。 尿管瘤の円蓋部切除には否定的意見も多いが，経尿道的瘤遠位部小切開は診断・治療上幾つかの利点が あり, 症例を選べば逆流は生じず時には更に操作を加える必要もなくなり試みてよい方法と考兵た。
} 


\section{緒言}

完全重複腎孟尿管は日常よく見る尿路奇形である。 教室では23症例の経験を既に報告済みだが1)，その後 更に22症例を経験して括り診断・治療上の諸問題を前 回と比較しつつ報告したい。

\section{対象・方法}

1977年から1985年までの 9 年間に新たに経験した完 全重複腎孟尿管の内, 何らかの臨床症状を呈して泌尿
器科的治療対象となった 22 症例を前回同様，・I，上半 腎所属尿管の尿管瘤11例，II．尿管逆流 8 例，III。瘤 も逆流もないが上半腎所属尿管に問題のあるもの 3 例 の 3 群に分けて検討した。

診断には IVP が尿毒症 1 例を除き全例に, VCU, 内 視鏡検査も全例に施行され逆流や尿管口の状態を始め 尿管 hiatus の脆弱性の表現と考兄られる瘤外翻 (eversion) の有無 2 )3)，尿管 hiatus の型 (common (2

表 1 I 群(尿管瘤) 11例症例 $\left(1-6\right.$ は既に報告分と重複 $\left.{ }^{2}\right)$

\begin{tabular}{|c|c|c|c|c|c|c|c|c|c|}
\hline 症 例 & 年齢・1 & & 症状 & 患側 & IVP(\#腎シンチ) & $\mathrm{VCU}$ & 内視鏡 (Hiatus) & 治 療 & 結 果 \\
\hline $\begin{array}{l}\text { 1. Y. K. } \\
\# 52-317\end{array}$ & 1.5歳 & 우 & 尿路感感 & 左 & $\begin{array}{l}\text { 上半腎 }(-) \text { drooping } \\
\text { lily. 膀脂内陰影欠損. } \\
\text { 対側巨大尿管 }\end{array}$ & 瘤外翻 & 瘤口不明 & $\begin{array}{l}\text { 上半腎尿管·瘤摘出 } \\
\text { 術 ( } 1 \text { 期的) }\end{array}$ & $\begin{array}{l}\text { 良好（対側巨大尿管改 } \\
\text { 善） } \\
\text { 病理 : 腎形成異常 }\end{array}$ \\
\hline $\begin{array}{l}\text { 2. M. N. } \\
\# 54-9 \\
\# 58-57\end{array}$ & 6歳 & 우 & 尿路感染 & 右 & $\begin{array}{l}\text { 上・下半腎共水腎症 } \\
\text { 瘤 cobra head }\end{array}$ & $\mid \begin{array}{l}\text { 瘤外翻 } \\
\text { 下半腎 } \\
\text { へ VUR }\end{array}$ & $\begin{array}{l}\text { 瘤口頸部 （C) } \\
\text { 姉妹尿管口 golf } \\
\text { hole }\end{array}$ & \begin{tabular}{|l|}
2 連銃式膀胜尿管新 \\
吻合術 (Paquin 法, \\
2 尿管縫縮, 1期的)
\end{tabular} & $\begin{array}{l}\text { VUR 再発(上 I 度, 下 } \\
\text { III-IV 度) } \rightarrow \text { 再手術 ( } \\
\text { Cohen 法 }+ \text { psoas hitch } \\
\text { )成功 }\end{array}$ \\
\hline \begin{tabular}{rl|} 
3. K. Y. \\
$\# 54-190$ \\
$\# 55-239$ \\
303 \\
\end{tabular} & 2か月 & 우 & $\begin{array}{l}\text { 尿路感染 } \\
\text { 新生児仮 } \\
\text { 死 }\end{array}$ & 左 & \begin{tabular}{|l|} 
上半腎 $(-)(\#+)$ \\
drooping lily. 膀胱 \\
内陰影欠損, 対側水 \\
腎症
\end{tabular} & & $\mid$\begin{tabular}{|l} 
瘤口頸部 $\quad(\mathrm{C})$ \\
瘤外翻
\end{tabular} & $\mid \begin{array}{l}2 \text { 連銃式膀胱尿管新 } \\
\text { 吻合術 }(\mathrm{P}-\mathrm{L} \text { 法, 縫 } \\
\text { 縮, } 1 \text { 期的) }\end{array}$ & $\begin{array}{l}\text { 良好（対側水腎症正常 } \\
\text { 化，上半腎機能改善） }\end{array}$ \\
\hline $\begin{array}{l}\text { 4. M. T. } \\
\# 54-225\end{array}$ & 3歳 & 우 & 尿路感染 & 左 & \begin{tabular}{|l|} 
上半腎 $(-)(\#+)$ \\
drooping lily, 膀胱 \\
内陰影欠損
\end{tabular} & $\begin{array}{l}\text { 瘤外翻 } \\
\text { 下半腎 } \\
\text { ヘ VUR }\end{array}$ & 瘤口不明 & \begin{tabular}{|l|}
2 連銃式膀胼尿管新 \\
吻合術 (P-L法, 縫 \\
縮, 1 期的)
\end{tabular} & $\begin{array}{l}\text { 良好(対側一過性 VUR } \\
\rightarrow \text { 消失) }\end{array}$ \\
\hline $\begin{array}{cc}\text { 5. F. Y. } \\
\# 56-230 \\
\end{array}$ & 47歳 & 우 & 尿路感染 & 右 & \begin{tabular}{|l|} 
上半腎 $(-)$, 膀胼内 \\
陰影欠損
\end{tabular} & & \begin{tabular}{|l} 
瘤口頸部 （C) \\
${ }^{*}$ Ericsson定義外
\end{tabular} & \begin{tabular}{|l|} 
脳圧亢進のため手術 \\
せず
\end{tabular} & \\
\hline $\begin{array}{l}\text { 6. A. G. } \\
\# 57-278\end{array}$ & 4か月 & 우 & $\begin{array}{l}\text { 尿路感染 } \\
\text { 瘤脱 }\end{array}$ & 左 & $\begin{array}{l}\text { 上半腎 }(-)(\#-) \\
\text { drooping lily, } \\
\text { 膀脱内陰影欠損 }\end{array}$ & 瘤外翻 & 瘤口頸部 & $\begin{array}{l}\text { 上半腎尿管・瘤摘出 } \\
\text { 術 ( } 1 \text { 期的) }\end{array}$ & $\begin{array}{l}\text { 良好 } \\
\text { 病理：腎形成異常 }\end{array}$ \\
\hline $\begin{array}{l}\text { 7. M. U. } \\
\text { \#58-309 }\end{array}$ & 1歳 & 우 & 尿路感染 & 左 & $\begin{array}{l}\text { 上半腎 }(-)(\#-) \\
\text { drooping lily, } \\
\text { 膀胱内陰影欠損 } \\
\end{array}$ & 瘤外翻 & 瘤口頸部 & 手術待機中 & \\
\hline $\begin{array}{l}\text { 8. K. F. } \\
\# 59-88 \\
\# 60-131\end{array}$ & 8歳 & 우 & $\begin{array}{l}\text { 尿路感染 } \\
\text { 左側腹部 } \\
\text { 痛 }\end{array}$ & 左 & $\begin{array}{l}\text { 上半腎 }(-)(\#+) \\
\text { drooping lily, 膀胒 } \\
\text { 内陰影欠損, 対側完 } \\
\text { 全重複腎盂尿管 }\end{array}$ & $\begin{array}{l}\text { 両下半 } \\
\text { 腎へ } \\
\text { VUR }\end{array}$ & $\mid \begin{array}{l}\text { 瘤口頸部（C) } \\
\text { (caecouretero- } \\
\text { cele) }\end{array}$ & \begin{tabular}{|l|} 
1) TUR-瘤 \\
2)2連銃式膀胱尿管 \\
新吻合術(Cohen \\
法, 縫縮)
\end{tabular} & $\begin{array}{l}\text { 良好（瘤所属尿管へ } \\
\text { VUR出現するも瘤の } \\
\text { 最末端部がTURで処 } \\
\text { 理されて括り根治手術 } \\
\text { 容易） }\end{array}$ \\
\hline $\begin{array}{l}\text { 9. T. S. } \\
\# 59-21 \\
\# 60-188 \\
\end{array}$ & 3か月 & 우 & $\begin{array}{l}\text { 尿路感染 } \\
\text { 排尿困難 } \\
\text { 尿毒症 }\end{array}$ & 左 & $\begin{array}{l}\text { 上・下半腎共(\#ー)(\# } \\
\text { 対側巨大尿管)(IVP } \\
\text { 施行せず) }\end{array}$ & $\begin{array}{l}\text { 姉妹尿 } \\
\text { 管へ } \\
\text { VUR } \\
\end{array}$ & \begin{tabular}{|l} 
瘤口頸部 $\quad(\mathrm{S})$ \\
姉妹尿管口は傍尿 \\
管口憩室内 $\left(\mathrm{D}_{3}\right)$
\end{tabular} & $\begin{array}{l}\text { 1)膀胱瘦 } \\
\text { 2)右尿管皮虐瘻 }\end{array}$ & $\begin{array}{l}\text { 腎機能改善するも発育 } \\
\text { 遅延, いずれ左腎摘と } \\
\text { 右の undiversion予定 }\end{array}$ \\
\hline $\begin{array}{l}\text { 10. A. S. } \\
\# 60 \mathrm{E} 805\end{array}$ & 5か月 & 우 & 尿路感染 & 左 & \begin{tabular}{|l|} 
上半腎 $(-)(\#+)$ \\
drooping lily, 膀胱 \\
内陰影欠損, 対側不 \\
完全重複腎盘尿管
\end{tabular} & $\begin{array}{l}\text { 姉妹尿 } \\
\text { 管へ } \\
\text { VUR }\end{array}$ & 瘤口尿道 & $\begin{array}{l}\text { Transurethral dis- } \\
\text { tal incision of cele }\end{array}$ & $\begin{array}{l}\text { 良好 (IVP 上機能出現, } \\
\text { 姉妹尿管 VUR 消失) } \\
\text { 瘤所属尿管へ I 度 VU } \\
\text { VUR出現 } \rightarrow 10 \text { 月後 } \\
\text { 消失 } \\
\end{array}$ \\
\hline $\begin{array}{l}\text { 11. Y. A. } \\
\# 572401\end{array}$ & 24歳 & 우 & \begin{tabular}{l|} 
尿路感染 \\
左腎部痛
\end{tabular} & 左 & $\begin{array}{l}\text { 上半腎所属尿管拡張 } \\
\text { 瘤 cobra head }\end{array}$ & & $\left|\begin{array}{l}\text { 瘤口三角部 （C) } \\
{ }^{*} \text { Ericsson定義外 }\end{array}\right|$ & 経過観察中 & \\
\hline
\end{tabular}


本一緒の hiatus, C 型), separate ( 2 本別々の hiatus, $\mathrm{S}$ 型), intermediate ( $\mathrm{S}$ 型に似るが異所尿管は排尿筋 と三角部筋の間を走る。 I 型)）分類 ${ }^{1224)}$ に関する情報 を提供してくれた.CT が 5 例に, ${ }^{99 \mathrm{~m}} \mathrm{Tc}$-DTPAを用い
た腎シンチは13例に施行された。

\section{結果}

症例の内訳は表 1 ～ 3 にまとめた。

1. 性·年齢：全例女子。I 群の $9 / 11$ は小児で（1歳

表 2 II群 (VUR) 8 例

\begin{tabular}{|c|c|c|c|c|c|c|c|c|c|}
\hline 症 例 & 年龄・ & & 症状 & 患側 & IVP(\#腎シンチ) & VCU & 内視鏡 (Hiatus) & 治 療 & 結 果 \\
\hline $\begin{array}{l}\text { 12. M. K. } \\
\# 50-185\end{array}$ & 7歳 & 우 & 尿路感染 & 右 & 上半腎のみ造影 & $\begin{array}{l}\text { 上・下 } \\
\text { 半腎共 } \\
\text { VUR }\end{array}$ & $\begin{array}{l}\text { 尿管口傍尿管口顋 } \\
\text { 室内 }\left(\mathrm{D}_{3}, \mathrm{D}_{1}\right) \quad-\end{array}$ & $\begin{array}{l}\text { 膀脱尿管新吻合術 } \\
\text { (Paquin 法) +盲端 } \\
\text { 尿管摘出術 }\end{array}$ & $\begin{array}{l}\text { 良好 } \\
\text { 病理：腎無発生 }\end{array}$ \\
\hline $\begin{array}{l}\text { 13. N. K. } \\
\# 52-75\end{array}$ & 6歳 & 우 & 尿路感染 & 左 & 上半腎水腎症 & $\begin{array}{l}\text { 上・下 } \\
\text { 半腎共 } \\
\text { VUR }\end{array}$ & $\begin{array}{l}\text { 尿管口傍尿管口媳 } \\
\text { 室内 }\left(\mathrm{D}_{3}, \mathrm{D}_{1}\right) \quad-\end{array}$ & $\begin{array}{l}\text { 膀脱尿管新吻合術 } \\
\text { (Paquin 法) +盲端 } \\
\text { 尿管摘出術 }\end{array}$ & $\begin{array}{l}\text { 良好 } \\
\text { 病理：腎無発生 }\end{array}$ \\
\hline $\begin{array}{l}\text { 14. A. T. } \\
\# 52-48 \\
\# 58-137\end{array}$ & 6歳 & 우 & \begin{tabular}{|l} 
尿路感染 \\
排尿困難
\end{tabular} & 右 & 上·下半腎共 (一) & $\begin{array}{l}\text { 下半腎 } \\
\text { VUR } \\
\text { 対側 } \\
\text { VUR }\end{array}$ & $\begin{array}{l}\text { 尿管口傍尿管口憩 } \\
\text { 室内 }\left(\mathrm{D}_{3}, \mathrm{D}_{3}\right) \quad-\end{array}$ & $\begin{array}{l}\text { 1)両側膀朕尿管新吻 } \\
\text { 合術 } \\
\text { 2)腎尿管全摘術 }\end{array}$ & $\begin{array}{l}\text { 左 VUR 再発,神経因性 } \\
\text { 膀脱 } \rightarrow \text { 間欠的自己導尿 } \\
\text { 病理 : 上・下半腎共腎 } \\
\text { 形成異常 }\end{array}$ \\
\hline $\begin{array}{l}\text { 15. R. H. } \\
\# 52-135\end{array}$ & 3歳 & 우 & $\begin{array}{l}\text { 尿路感染 } \\
\text { 尿失禁 }\end{array}$ & 右 & 上-下半腎共正常 & \begin{tabular}{|} 
下半腎 \\
へ VUR
\end{tabular} & 尿管口頸部 （C） & $\begin{array}{l}\text { 保存的治療(抗菌剤 } \\
\text { •抗コリン剂) }\end{array}$ & 良好 (VUR 自然消失) \\
\hline $\begin{array}{l}\text { 16. S. I. } \\
\# 55-133 \\
\# 57-235 \\
\# 58-254\end{array}$ & 1歳 & 우 & $\begin{array}{l}\text { 尿路感染 } \\
\text { 排尿時痛 }\end{array}$ & 両側 & $\begin{array}{l}\text { 右上半腎のみ水腎症 } \\
\text { 他正常(\#+) }\end{array}$ & $\begin{array}{l}\text { 右上半 } \\
\text { 腎VUR } \\
\text { 左上・ } \\
\text { 下半腎 } \\
\text { 共 VUR }\end{array}$ & $\begin{array}{l}\text { 尿管口両側共頸部 } \\
\text { (左下半腎尿管口 } \\
\text { golf hole) (C / C ) }\end{array}$ & $\begin{array}{l}\text { 両側2連銃式膀胱尿 } \\
\text { 管新吻合 (Cohen } \\
\text { 法) }\end{array}$ & 良好 \\
\hline $\begin{array}{l}\text { 17. E. M. } \\
\# 58-139\end{array}$ & 32歳 & 우 & $\begin{array}{l}\text { 尿路感染 } \\
\text { 右側腹部 } \\
\text { 痛 }\end{array}$ & 右 & $\begin{array}{l}\text { 上半腎 }(-)(\#-) \\
\text { drooping lily, 膀胱 } \\
\text { 内陰影欠損 }\end{array}$ & \begin{tabular}{|} 
下半腎 \\
へ VUR
\end{tabular} & $\begin{array}{l}\text { 尿管口頸部(狭窄) } \\
\text { 右三角部に一見瘤 } \\
\text { 状の膨隆) }\end{array}$ & $\begin{array}{l}\text { 上半腎尿管摘出術 } \\
\text { (可及的尿管摘出) }\end{array}$ & $\begin{array}{l}\text { 良好(下半腎への VUR } \\
\text { 消失, ただし尿管 } \\
\text { stumpへVUR出現) } \\
\text { 病理：腎形成異常 }\end{array}$ \\
\hline $\begin{array}{l}\text { 18. M. A. } \\
\# 57-228\end{array}$ & 60歳 & 우 & $\begin{array}{l}\text { 尿路感染 } \\
\text { 血尿 }\end{array}$ & 左 & \begin{tabular}{|l|} 
上半腎 $(-)(\#-)$ \\
drooping lily, 対側 \\
不完全重複腎孟尿管 \\
(結石合併)
\end{tabular} & $\begin{array}{l}\text { 上半腎 } \\
\text { へ VUR }\end{array}$ & 尿管口頸部 （I） & $\begin{array}{l}\text { 上半腎尿管摘出術 } \\
\text { (尿管完全摘出) }\end{array}$ & $\begin{array}{l}\text { 良好 (一過性尿漏 } \rightarrow \\
\text { splint 留䓢で解決) } \\
\text { 病理 : 炎症・水腎症 }\end{array}$ \\
\hline $\begin{array}{l}\text { 19. I. T. } \\
\# 60-349\end{array}$ & 28歳 & 우 & $\begin{array}{l}\text { 尿路感染 } \\
\text { 排尿困難 }\end{array}$ & 両側 & $\begin{array}{l}\text { 両下半腎瘦痕性変化 } \\
(\#+)\end{array}$ & $\begin{array}{l}\text { 両下半 } \\
\text { 腎VUR }\end{array}$ & $\begin{array}{l}\text { 尿管口三角部 (C) } \\
\text { (左は頸部寄り) }\end{array}$ & \begin{tabular}{|l} 
両側2連銃式膀胱尿 \\
管新吻合術 \\
$(\mathrm{P}-\mathrm{L}$ 法)
\end{tabular} & 良好 \\
\hline
\end{tabular}

表 3 III群 3 例

\begin{tabular}{|c|c|c|c|c|c|c|c|c|}
\hline 症 例 & 年齢・性 & 症状 & 患側 & IVP(\#腎シンチ) & $\mathrm{VCU}$ & 内視鏡 (Hiatus) & 治 療 & 結 果 \\
\hline $\begin{array}{l}\text { 20. } \\
\text { A. Y. } \\
\# 53-79 \\
\# 55-285\end{array}$ & 6か月 우 & $\begin{array}{l}\text { 尿路感染 } \\
\text { 尿失禁 }\end{array}$ & 左 & $\begin{array}{l}\text { 上半腎 }(-)(\#-) \\
\text { drooping lily, 対側 } \\
\text { 不完全重複腎孟尿管 }\end{array}$ & $\begin{array}{l}\text { 扗張尿 } \\
\text { 管によ } \\
\text { る膀腅 } \\
\text { 変位 }\end{array}$ & $\begin{array}{l}\text { 尿管口腟前庭（I） } \\
\text { (手術時判明) }\end{array}$ & $\begin{array}{l}\text { 上半腎尿管摘出術 } \\
\text { (可及的尿管摘出) }\end{array}$ & $\begin{array}{l}\text { 良好 } \\
\text { 病理 : 腎形成異常, } \\
\text { 尿管筋形成異常 }\end{array}$ \\
\hline $\begin{array}{l}\text { 21. S. I . } \\
\# 55 \mathrm{SH} 51\end{array}$ & 5歳 우 & $\begin{array}{l}\text { 尿管性尿 } \\
\text { 失禁 }\end{array}$ & 左 & 上半腎(一) & & $\begin{array}{l}\text { 尿管口胵前庭(S?) } \\
\text { (手術時判明) }\end{array}$ & $\begin{array}{l}\text { 上半腎尿管摘出術 } \\
\text { (部分的尿管摘出) }\end{array}$ & $\begin{array}{l}\text { 良好 } \\
\text { 病理：腎形成異常 }\end{array}$ \\
\hline $\begin{array}{l}\text { 22. A. W. } \\
\# 60-279\end{array}$ & 3歳 우 & $\begin{array}{l}\text { 尿管性尿 } \\
\text { 失禁 }\end{array}$ & 右 & $\begin{array}{l}\text { 上半腎やや造影不良 } \\
(\#+) \text {, 春椎奇形, CT } \\
\text { で尿管下端扗張強い }\end{array}$ & & 尿管口胵内 （S） & 尿管尿管吻合術 & 良好 \\
\hline
\end{tabular}


以下 5 例), 平均年齢 8.3 歳（前回 11.0 歳）と低年龄化 した. II 群も $5 / 8$ 小児だが平均年齢 18.4 歳と不変で あった. III群は全て小児で平均年齢 2.8 歳(前回 17.8 歳) とかなり低年齢化した。

2. 初発症状：I，II群は腎孟腎炎様症状を全例に認 めた。I 群では瘤脱，排尿困難，尿毒症，II群では排 尿困難，尿失禁，血尿も認めたＩII群では尿路感染は 1 例の久で尿失禁を全例に認めた（内 2 例は尿管性尿 失禁).

3. 患側と対側上部尿路：I 群は右 2 , 左 9 と左に多 く(前回は差なし)。II群は右 4 , 左 2 , 両側 2 , III群 は右 1 , 左 2 で全体では右 7 , 左 13 , 両側 2 と左に多 かった(前回は差なし)。対側完全重複を I 群 1 例，II 群 2 例，不完全重複を各群 1 例ずつ認めた。

4. レ線学的検查所見 (A) IVP：I 群では尿毒症で 未施行の 1 例を除き全例下半腎は造影されたが，2 例 は上半腎も造影された。 大多数の 7 例は drooping lily 像を呈したが 1 例は重複腎を疑えなかった，姉妹尿管 偏位 4 例，瘤による膀胱底陰影欠損 8 例，cobrahead 像 2 例の他対側水腎症も 3 例に認めた. II 群では上, 下半腎共造影 3 例, drooping lily 2 例, 下半腎造影な し（傍尿管口款室例） 3 例であった．III群では下半腎 のみ造影 2 例, 上, 下半腎共造影 1 例で後者では姉妹 尿管偏位も認めた。（B）VCU：I 群では姉妹尿管へ の逆流を 5 例，対側への逆流を 1 例認めたが，瘤所属 尿管への逆流は今回は認めなかった。瘤外翻は 5 例に 認めた。II群では逆流は上・下半腎共 2 例, 下半腎の み 4 例, 上半腎の及 1 例で, 両側例（症例16）では右 下半腎以外の3segments に逆流を認めた。III群では拡 張尿管による膀胱圧排像を 1 例認めた。（C） CT : 5 例に施行され（症例 $5 \cdot 9 \cdot 17 \cdot 18 \cdot 22 ）$ 内 4 例で拡 張した腎孟・尿管が描出された。

5.内視鏡検查：I 群では瘤が膀胱頝部に達するか 更に尿道内に及ぶもの（Ericsson の異所性尿管瘤の定 義に合致 $\left.{ }^{2}\right)$ が 9 例認められた，尿管口の位置は膀胱頝 部 近位尿道 7 , 遠位尿道 1 , 三角部 1 , 不明 2 で, 瘤外翻は 6 例で確認された。症例 8 は瘤遠位部に小切 開を加え内部から観察し caecoureterocele と診断し た. 姉妹尿管口は 2 例のみ異常で（内 1 例は傍尿管口 秘室内 $\left(\mathrm{D}_{3}\right)$ 開口 $\left.{ }^{5 / 6)}\right)$, 対側尿管口は全例ほぼ正常で あった。 II 群では尿管口の位置は傍尿管口㮩室内 3 例 6 尿管 $\left(D_{1} 2, D_{3} 4^{5) 6}\right)$ ，膀胱䅡部 4 例 5 尿管で, 残り の 1 例 2 疝管は三角部側角にあった。形態は䄸室内 6 , golf hole 3, 一見瘤状 1 ，正常 1 であった。姉妹尿管
口は 1 例の及異常，対側尿管口は全例正常であった。 III群では症例22の久腔内開口部が確認されたが，他の 2 例は上半腎所属尿管開口部不明で手術時腔前庭と確 認された. Hiatus の型は主に内視鏡検査で判定し手術 時最終的に確認した。 I 群では $\mathrm{C}$ 型 7 例, $\mathrm{S}$ 型 4 例, II 群では C 型 3 例 (両側 2 例), I 型 2 例 (但し傍尿管 口憩室内開口は型別から除外), III群では I 型, $\mathrm{S}$ 型, 不明各 1 例であった。この不明例は手術時尿管下端が 未処置のためで，尿管性尿失禁 $(+) \cdot$ 尿管拡張 $(-)$ などから尿道括約筋外走向が示唆され $\mathrm{S}$ 型と思われ る.

6. 腎シンチ：13例に施行. I 群 7 例は全て IVP 上 無機能ながら内 4 例で集積（十）で，これらは腎保存 となった（hiatusは全てC型. 逆に残りの 3 例は $\mathrm{S}$ 型). II 群 4 例中 2 例は IVP 上無機能で RI 集積も(-) だった( I 型 hiatus). III群では IVP 上無機能腎とやや 造影不良の各 1 例に施行され, 前者は集積 (一) だが ( I 型 hiatus)，後者は患腎の約 $36 \%$ 集積が上半腎部 に見られた。.以上のようにIVP上無機能でもC型 hiatus 例では腎シンチ上集積（十）が多かった。

7. 治療法（表 4)：I 群 8 例, II 群 7 例, III群 3 例 計18例に外科的治療を施行した。I 群では尿管縫縮を 伴う 2 連銃式膀胱尿管新吻合術を 4 例に施行したが, 内 1 例は瘤末端部を TUR で処理後》) 2 期的に行なっ た. S 型 hiatus の 2 例は姉妹尿管には一切手を加党 ず2)上半腎尿管全摘術を施行した。症例 $9 \cdot 10$ の詳細は 後述する. II群では膀胼尿管新吻合術を 4 例に施行, 内 2 例は下半腎所属となるはずの盲端尿管摘出も行 なった(他の 2 例は両側共 2 連銃式に新吻合)。2 例に 上半腎尿管摘出術を施行した。症例14は両側新吻合術 後逆流再発し，右腎機能も改善なく右上，下半腎尿管 全摘術となったＩII群では上半腎尿管摘出術を 2 例に 施行したが，尿管末端拡張なく腔前庭開口なので尿管 の完全摘出は行なわなかった。他の 1 例は本邦では報 告の少ない尿管尿管吻合術を施行した。

8. 結果：術後観察期間は 3 力月から 9 年であるが, 4 例に問題が発生した。内訳は, (1) VUR 再発（症例 2), (2)対側 VUR 出現(症例 4), (3)残尿管へ逆流出現 （症例17），(4)姉妹尿管損傷による尿漏れ（症例18）で (2)はすぐ消失，(4)も尿管 splint 留置ですぐ消失した。 (3)は尿管口が狭窄状なので尿管末端は可及的摘出に止 めた例でこれもすぐ消失した．結局大きな後遺症は(1) のみで，内視鏡検查では両尿管口は開大し下半腎所属 尿管口は当初の位置から約 $2 \mathrm{~cm}$ 後退していた。 2 連銃 
(A) 腎摘出術（7例）

（1）上半腎尿管完全摘出術

（2）上半腎尿管可及的摘出術

（3）上半腎尿管部分摘出術

（4）腎尿管完全摘出術

（B）腎保存手術 (11例)

（1） 2 連銃式膀胱尿管新吻合術

(2) 膀脱尿管新吻合術十盲端尿管摘出術

（3）尿管尿管吻合術

(4) Transurethral distal incision of cele

(5) 対側 Transient supravesical diversion
-3 例 ( I 群 2 例, II 群 1 例)

-2 例（II群, III群各 1 例)

-1 例 (III群)

-1 例 (II 群)*

-6 例 (I 群 4 例**, II 群 2 例)

- 2 例 (II 群)

-1 例 (III群)

-1 例 ( I 群)

-1 例 ( I 群 $)^{* * *}$

*両側膀胼尿管新吻合術失敗後 ** 1 例はTUR-瘤後 2 期的に *** 左腎摘と undiversion 予定中

式新吻合術に際し common sheath に包末れている一 方の尿管のみを固定したこと, 下半腎所属尿管縫縮面 が膀胼粘膜側に来たため縫合部が離開したことなどが 原因と考光られた。 5 年後 Cohen 法と psoas hitch 併 用の再手術で根治した。瘤残存による合併症は今回は 見られず，対側水腎症改善・姉妹尿管への逆流消失・ 腎機能改善も各 2 例ずつ認めて扣り全体的には充分満 足すべき結果であった，一方，前回の報告での 3 例の 後遺症 (1)尿感染持続, (2)下半腎への逆流再発, (3)下 半腎機能消失) は, 後 2 者のみが未解決であった。(2) は軽快傾向で(3)も特に高血圧などの問題は起していな いが，(3)原因として血管損傷一腎茥部捻転が考兄ら れ8), 将来腎摘も考号られる。

9。病理：摘出標本の検討は 9 例に可能で, I 群 2 例 (上半腎) は形成異常腎であった ${ }^{910)}$ 。II 群 5 例中 3 例 は傍尿管口憩室例で下半腎欠損（盲端尿管） 2 ，上。 下半腎共形成異常腎（下半腎の方が高度）1 2 尿管芽 分岐位置異常説を支持する所見であった ${ }^{5 / 6) 99}$ 。他の 2 例 (上半腎) では水腎症と形成異常腎であった。III群 2 例も形成異常腎であったが，症例20は尿管筋も筋束 形成なく dysplastic ureter ${ }^{11)}$ 考兄られた。一方， hiatus 型別に腎機能と腎形成異常の頻度を見ると C 型では10/11が機能陽性で唯一の陰性例は腎シンチ未 施行例であった。I・S 型では7/8が無機能で検索した4/ 5に腎形成異常を認めた。尿管口の異所性では差は出 ず9)，前回同様 I $\circ \mathrm{S}$ 型で無機能・形成異常腎の頻度が 高かったが1), 唯一 $\mathrm{S}$ 型でも腔内開口の症例22は腎機 能良好であり注目された。

以下興味深い 3 症例を供覧する。

<症例 $9>3$ 力月女児. 1983年 7 月 6 日満期産 2,700 $\mathrm{g}$ で出生 ( 2 卵性双胎, 妊娠17週に切迫流産)。生後 3
週頃左側腹〜下腹部腫瘤と尿毒症指摘され腹膜灌流と 膀胱瘦造設施行, 以後腹部腫瘤は消失し腎機能も BUN $63 \rightarrow 40$, Cr 2.4 $\rightarrow 2.0$ とやや改善した。腎シンチ 上左腎には全く $\mathrm{RI}$ 集積なく右腎も高度水腎水尿管症 が疑われた（図 1)。しばしば尿の流出が不良で発熱や 全身状態の悪化を繰返すため 10 月 3 日当科転院。体重 $4.8 \mathrm{~kg}$, 高度貧血で腎機能は BUN $55, \mathrm{Cr} 1.9$ で新鮮血 輸血と補液・抗生剂で一般状態は改善した。膀胱造影 では左尿管逆流と瘤壁による尿道閉塞を認めた。内視 鏡検査では膀胼内は肉柱高度で右尿管口は不明, 左側 には膀脱頝部に開口し一部尿道に及ぶ尿管瘤を認めた が, 詳細は観察不能であった。膀胱㾞の効きが悪い原 因として瘤壁の関与が考兄られ, 膀脱高位切開で瘤壁 切除・膀胱瘦再造設を施行, 右尿管には膀胱外から splint を留置した。術後 splint から右腎を造設すると 代償性肥大と胎児性分葉著明な腎と拡張・蛇行著明な 尿管が造影された（図 2)。その後腎機能はBUN 18, Cr 1.2 と著しく改善した。以上の経過から右腎機能保 持のためには膀胱㾇のみでは不十分と判断，11月21日 右 Roux Y 形尿管皮膚瘦を造設し膀胱瘦は抜去し以 後外来経過観察とした。その後約 1 年半特に問題なく, 1985年 6 月 14 日病態の正確な把握を目的に再入院し た。身長 $80.0 \mathrm{~cm}$, 体重 $10.2 \mathrm{~kg}$ (共に-2S.D.)で腎機能 は BUN 29, Cr 1.1, Ccr $31.6 \mathrm{ml} / \mathrm{min}$ であった。内視 鏡検査では右尿管口はやや pin hole 状で左瘤壁が一 部残存していた。瘤所属尿管の hiatus は左三角部側角 に沿って認めたが，比較的 tight で内視鏡を尿管内腔 へは進められなかった。残存瘤壁上外側に直径約 1.5 $\mathrm{cm}$ の憩室があり下半腎所属尿管は $\mathrm{D}_{3}$ の位置に開口 し内視鏡は容易に内腔へ插入可能であった。両尿管は 全く別個に膀脱壁と接続して括り hiatusは S 型と考 
図 1 腎シンチ $(\mathrm{P} \rightarrow \mathrm{A})$

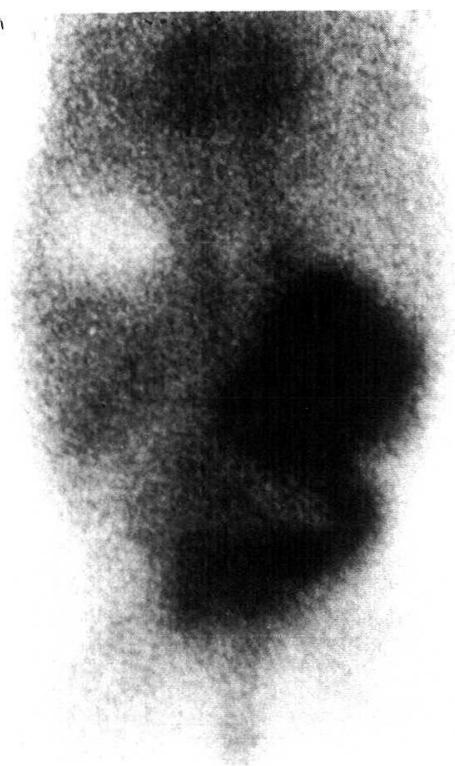

図 2 尿管 splint より造影した右腎・尿管.

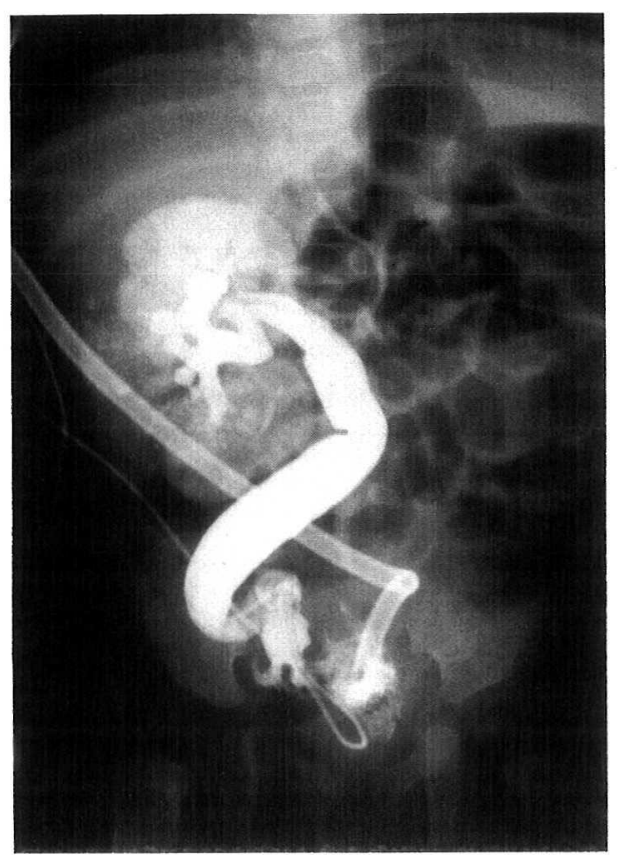

えた。左 2 尿管への術中 RP を図 3 に示した。その後 VCUで残尿なく排尿しているのが初めて確認された 他，内視鏡所見に一致する左下半腎への IV 度の逆流 を認めた(図 4)。以上より左完全重複腎盘尿管に合併
図 3 左 RP

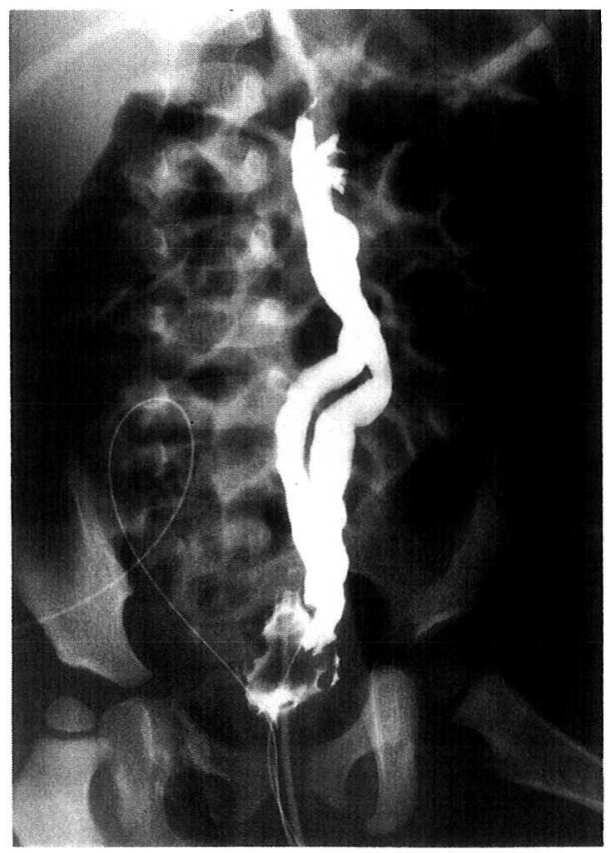

図 4 VCU

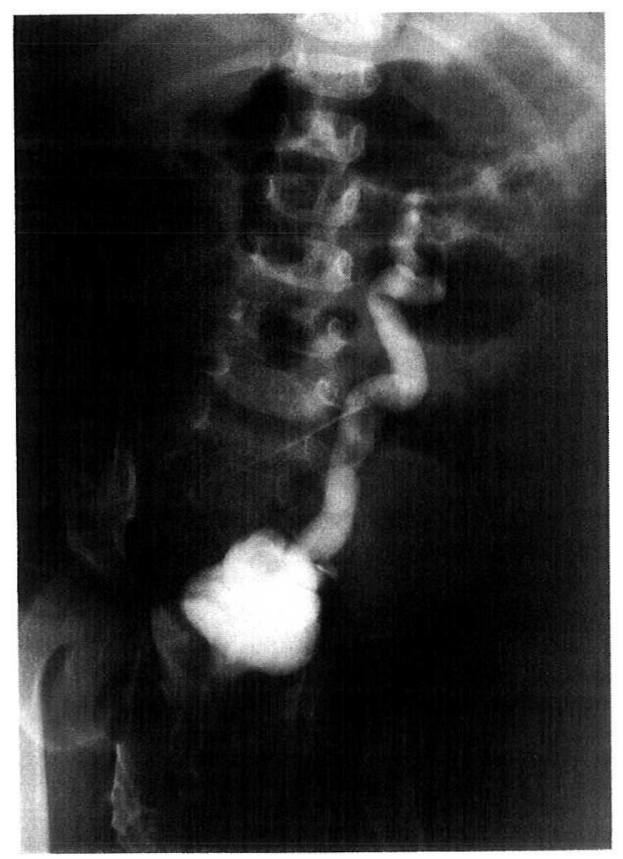

した左傍尿管口敗室を伴う逆流性巨大尿管症, 左異所 性尿管瘤による尿閉, 右巨大尿管症と結論, いずれ左 腎尿管全摘術と右 undiversion る予定しているが，こ 
因 5 術前 IVP

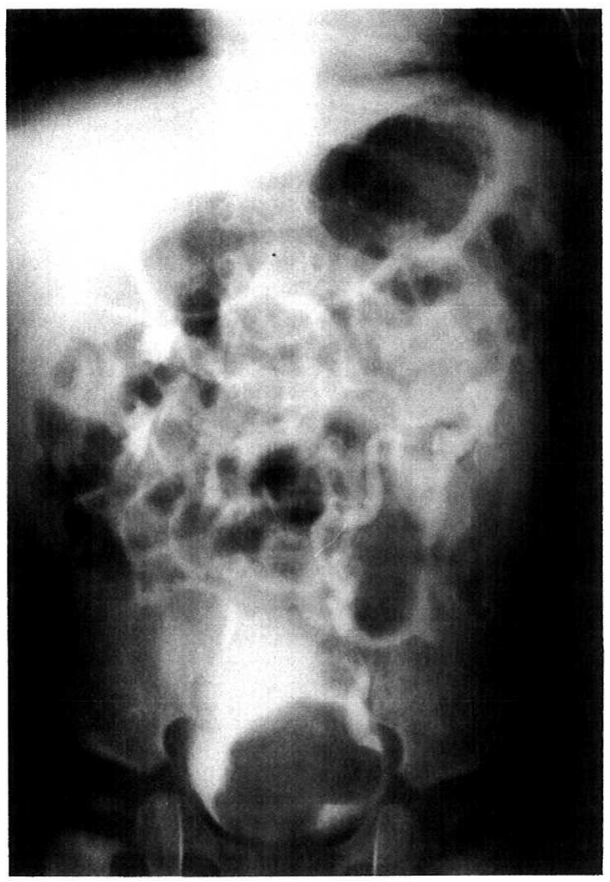

の様な重篤例では早期に supravesical diversion を施 行し全身状態の改善を計った後精査を進めるべきで あったと反省させられた。

<症例10>5 カ月女児. 1984年 6 月19日発熱・尿路 感染にて某小児科から紹介された. IVP で右不完全重 複腎孟尿管, 左 drooping lily 像・尿管偏位の他膀脱底 に大きな陰影欠損を認めた（図 5 ). VCU では左下半 腎所属尿管への I 度の VUR と瘤の尿道内陥入を見た が外翻はなかった。腎シンチでは左上半腎に左腎全体 の約30\%の集積を認めた(図 6 ). 1985年 5 月 10 日入院, 内視鏡検査では瘤は外翻なくその遠位端は遠位尿道に 達し外尿道口後壁に開口していた。そこから予め尿管 カテ挿入後小児用切除鏡で瘤壁を膀脱䅡部の所で横切 開, 瘤内に入ると先のカテが確認され, また異所尿管 の hiatus はC 型と判明した. hiatus は tight でその奥 へは内視鏡は入らなかった。術中 RP で拡張・蛇行した 瘤所属尿管が造影された。以上の操作で尿の drainage 改善と瘤の虚脱が図れたと考兄られた。術後 2 週目の IVPで以前は造影されなかった左上半腎が造影され た他, 下半腎の drooping lily 像も若干軽快した（図 7 ).VCU では姉妹尿管への逆流は消失した反面瘤所 属尿管に I 度の逆流が出現したが，臨床的には尿感染 もなく順調で尿管拡張の改善に従い自然に消失するも
図 6 腎シンチ $(\mathrm{P} \rightarrow \mathrm{A})$

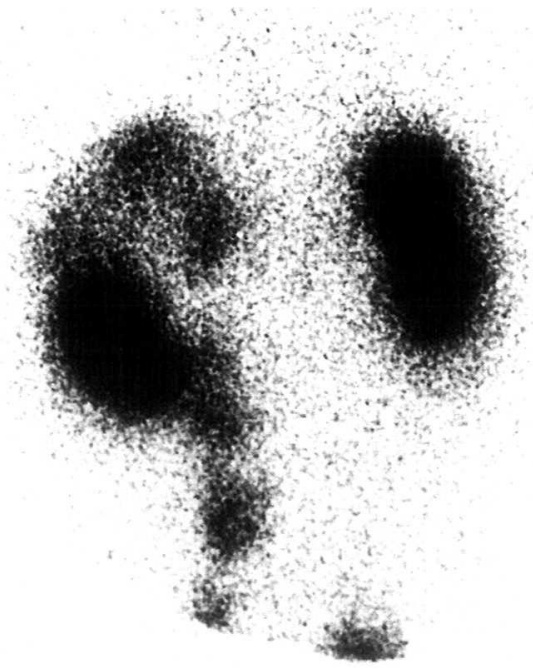

図 7 術後 IVP (矢印：上半腎盘)

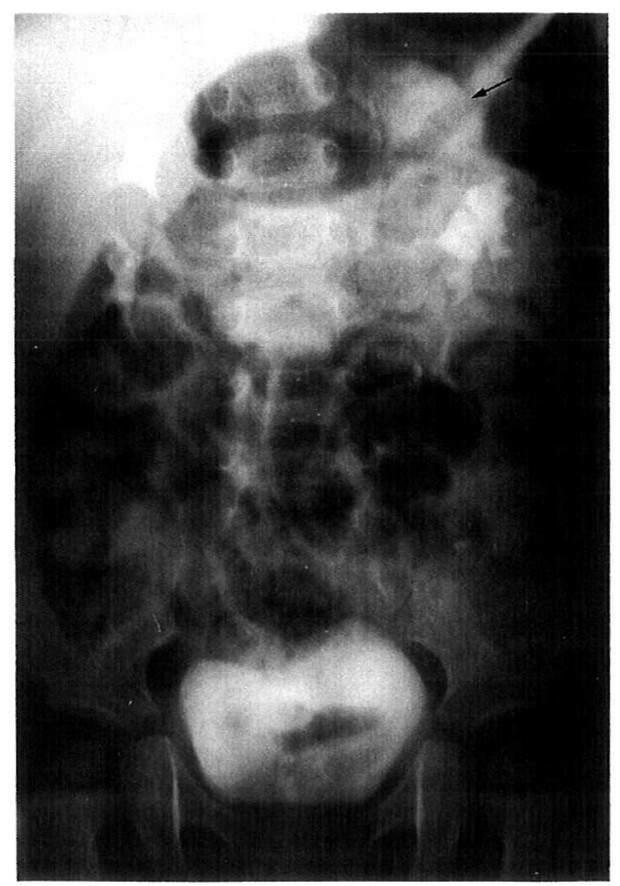

のと期待している（10カ月後の現在消失を確認）.

<症例17>32歳主婦. 1982年より時々右側腹部痛あ り某泌尿器科で膿尿指摘された。 IVPで右尿管瘤を疑 われ1983年 4 月 22 日当科入院. IVP で右 drooping lily 
図 8 IVP（矢印：膀脱内陰影欠損）

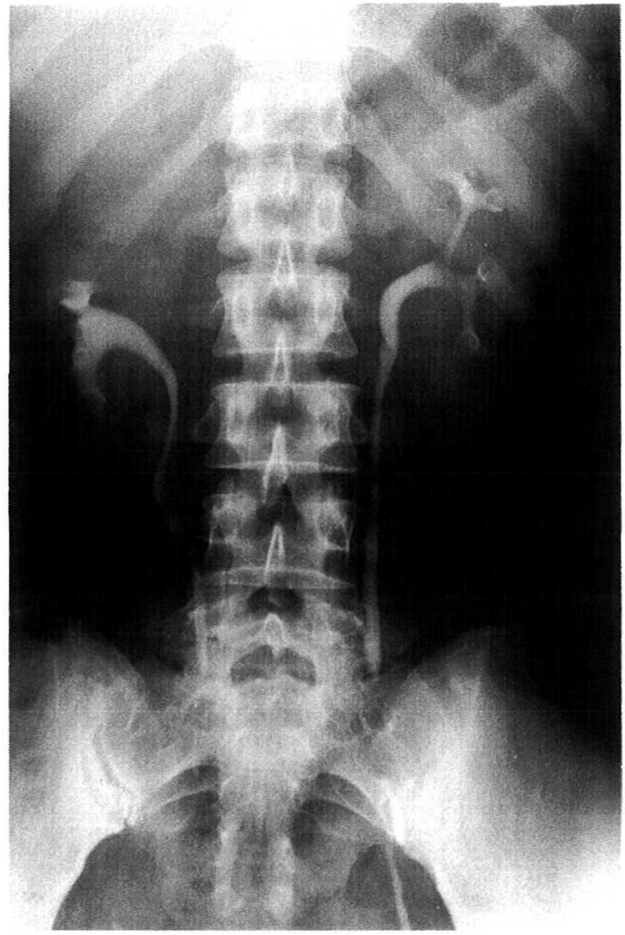

図 $9 \mathrm{CT}$ ( $\mathrm{L}$ : 下半腎所属尿管, $\mathrm{U}$ : 上半腎所属尿管)

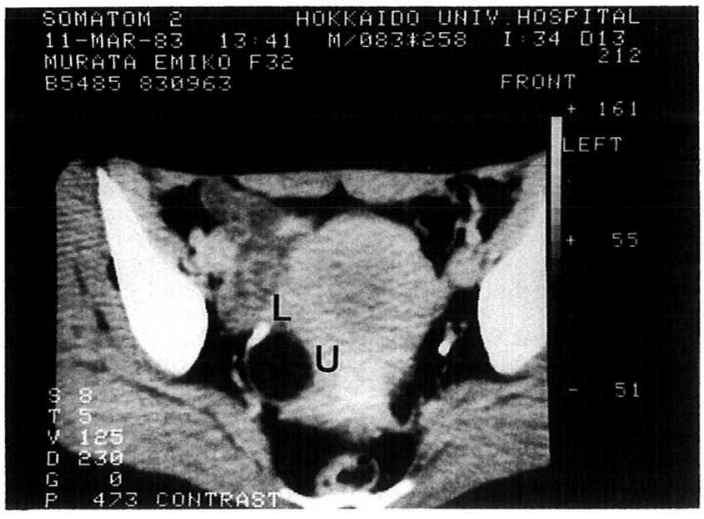

像・尿管下端の走向異常の他, 膀胱底に卵円形の陰影 欠損を認めた（図 8).VCU では右下半腎所属尿管に I 度の逆流を認めた。内視鏡検査では尿管瘤はなく上 半腎所属尿管によると思われる右三角部の膨隆を認め たが尿管口は不明だった。CT では右上半腎は囊状で enhance されず所属尿管も拡張しその下端は膀胱内へ 突出していた(図 9)。腎シンチでは右上半腎には集積 を認めなかった(図10)。以上より 5 月 4 日右上半腎尿 管摘出術を施行した。尿管より順行性にカテを挿入す
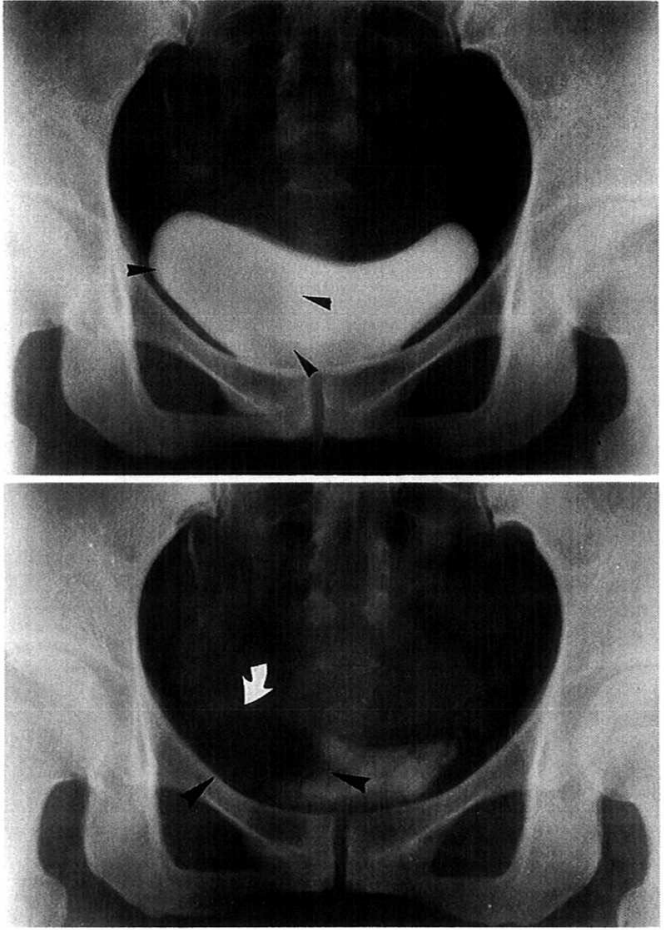

図10 腎シンチ $(\mathrm{P} \rightarrow \mathrm{A})$

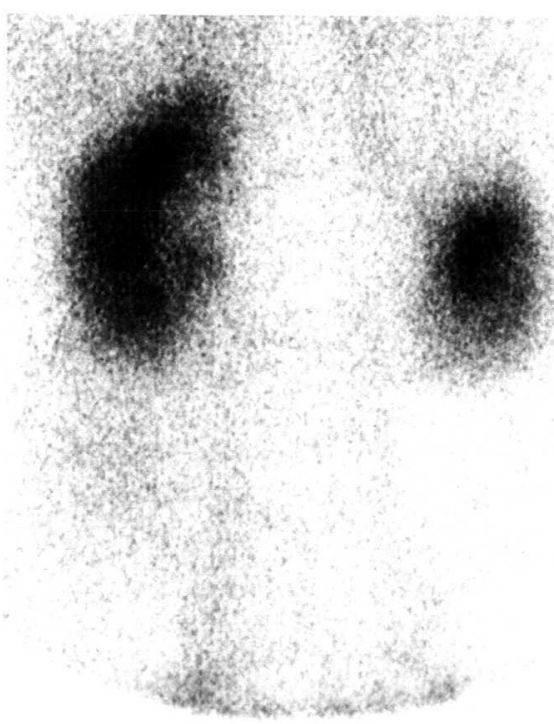

ると尿管口は膀胼䅡部にあり狭窄状なので尿管末端は 膀胱近くで切断・閉鎖し可及的摘出に止めた。この操 作で尿管瘤は否定され hiatus は I 型と判明した。姉妹 尿管への逆流は拡張尿管による圧迫の影響と考兄られ 
術後 VCUで消失した。経過順調で退院した。

\section{考 察}

1. 臨床統計・症状：重複腎孟尿管が圧倒的に女児に 多く，何らかの症状を有する例は再発性，難治性尿路 感染を呈する点など前回と大差なかった ${ }^{11}$ 。初診時年 齢も，I・III群で低年齢化した。胵前庭開口で尿管性尿 失禁陽性例と陰性例とがあるが，これは hiatus の差で C 型・I 型では尿管が外括約筋内を通るため尿失禁が 起りにくいと考兄られた113) 15).

2. 診断：レ線学的診断の詳細は成書に譲るが, 特徵 的所見が全てそろらとは限らず重複腎の存在を疑って 検査する必要がある ${ }^{16)}$. VCU では瘤の外翻を喤室と誤 診してはいけない2)16)。腎シンチはIVP 上排泄像の判 断しにくい例でもその残存機能を良く表現し，また腹 部ガスの影響も受けない他コンピューター処理によ り，上下半腎の区域別機能もある程度定量化可能で, 腎保存か摘出かの方針決定上参考になる ${ }^{117) 18)}$. 超音波 検査は少数例で検討から除いたが，瘤や㧪張した上部 尿路の検索に有用である ${ }^{17)}$.

内視鏡検査は極めて重要で特に瘤外翻の有無と hiatus の型の検討は治療方針決定上有用である ${ }^{244}$. そ の際 VCU と同様外翻した瘤を憩室と誤診しないよう 膀脱容量を増减した動的観察が大切である ${ }^{16)}$.な招 I 型 hiatus の確診は内視鏡検査のみでは難しく手術時 所見によることが多い。瘤では外翻なければ遠位部に 小切開を加㝋ても逆流出現は殆ど心配なく，そこから 内視鏡を瘤内に捰入すれば瘤外からの観察と併せて hiatus の型の決定が容易となる（瘤外翻例ではそのま まで充分観察可能である).瘤遠位部小切開の利点とし て手術までの間通過障害が除かれた状態で腎機能回復 の有無を見られることも挙げられる ${ }^{199}$. 内視鏡検査は 症例17の如く瘤による陰影欠損と単に拡張尿管が膀胱 三角部を押上げている場合との鑑別にも有用で，われ われは単一性異所開口尿管でも同様の経験がある ${ }^{20)}$.

3. 発生学的検討：所属腎機能の良し悪しが尿管口 の異所性の程度のみでは説明し切れない例があること が,われわれが hiatus の型に注目したさっかけであっ た ${ }^{1) 9}$. Stephens は重複尿管の大多数は 2 本一緒の hiatus を通り (C型)，全く別の hiatus を通ること（S 型)は性路開口を除くと稀としたが21), 尿路開口の $\mathrm{S}$ 型 もとれ程少なくはないと最近 Shapiroは報告してい る8) (I 型の記載はわれわれのみ). 実際所属腎機能の 良し悪しと腎形成異常の頻度は hiatus の型と良く平 行していた。但し S 型 hiatus でも胵内開口例では腎機
能良好例があり, Müller 氏管の関与や Gartner 氏管の 腔への穿孔などの要因を考えると腔内開口のあるもの は高度の異所開口ではない可能性が考学られた ${ }^{910)}$. 一方，下半腎所属尿管が傍尿管口喤室内に開口した症 例 9 も興味深い, 下半腎への逆流や水腎症は瘤の圧 排・変形のためと理解されているが，それと無関係な 内因性の下半腎異常としては唯一巨大尿管症の報告が あるが22), 症例 9 のような傍尿管口䕀室内開口は未だ 報告を見ない. 開口部が最も異所性高度の $\mathrm{D}_{3}$ であり下 半腎機能 $(-)$ も形成異常腎のためと考兄られる ${ }^{5}$. 即 ちこの症例では Wolff 氏管の頭側から分岐した尿管 芽末端は異所性尿管瘤に，尾側から分岐した尿管芽末 端は早期に膀胼内に組み込をれて傍尿管口喤室になっ たと考えられる，尿管瘤，傍尿管口憩室をそれぞれ膀 胱内外での尿管末端の異常拡張とすれば"1), 膀胼尿道 管（vesicourethral canal）の急速な拡張が尾側で瘤を 頭側で䄭室を発生させたと理解することも出来る.

4. 外科的治療法：腎機能が著しく不良の場合上半 堅は摘出されるが，姉妹尿管損傷を避けるため特に尿 管瘤では尿管末端部の処置は不要とする意見が多 (24) 31). 瘤の虚脱なく問題が生じた時処置すれば良い とされるが25227)29)，その可能性は約 $20 \%$ で決して少な くはない27)29)。 また半腎摘出後逆流が出現することも 多い(“delayed VUR”). 最近は安全かつ 1 期的に完全

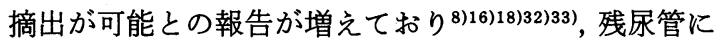
悪性腫瘍発生もありらることから ${ }^{16)}$ ，現在われわれは 尿管末端は瘤も含めて可及的に完全摘出すべきと考兄 ている（胵前庭や性路開口例では部分的摘出で充分）。 完全摘出法としては患尿管断端に掛けた支持系を膀脱 内に引出し尿管を反転させ切断する transvesical intussusception ureterectomy (Howerton) が安全で ある ${ }^{1) 4}$. 可及的摘出法は尿管剝離困難な所で患尿管を 切断し残尿管外側面に hiatus までの縦切開を加兄, 余 分の尿管壁を切除後姉妹尿管に狭窄の来ない程度に hiatus を補強する Johnston 法が良(1)4)8)12). hiatus が $\mathrm{S}$ 型で尿管間膜が比較的粗な場合完全摘出は容易だ が2)，尿管剥離には Hendren らの方法も参考にな $ろ^{33)}$.

腎保存手術ではCohen 法による膀脱尿管新吻合術 が成績向上に寄与しており ${ }^{8)}$ ，われわれも再手術例を 含め 3 例に施行し満足すべき結果を得た。一方尿管縫 縮を避けるため腎孟尿管吻合術 ${ }^{8)}$ や尿管尿管吻合術 ${ }^{34}$ を推す意見もある．膀胱内操作不要であり yo-yo 現象 や尿漏れ，水腎症も臨床的に問題となることはなく， 
症例を選べば良い治療法である。

最後に経尿道的瘤壁切除の意義について述べる。一 般には逆流必発とされ緊急時以外禁忌とされる2527)331 が，単純性尿管瘤では瘤遠位部小切開は有用で7)19)わ れわれる瘤外翻のない 6 例 9 尿管に本法を施行, 逆流 を生じずに通過障害の解除に成功している，異所性尿 管瘤では未だ否定的意見が多いが7), 上半腎機能評価・ 下半腎減圧など利点もある ${ }^{1926)}$. 今後の検討を要する がMonfort らは出生前診断も可能な今日では無症状 な新生児に早期減圧を図ることが異所性尿管瘤の治療 法に变化をもたらす可能性があると述べている ${ }^{19}$. 仮 に逆流が生じても瘤の最末端部が処理済みであり特に caecoureterocele では根治手術が容易となる利点も ある。

\section{結 語}

最近 9 年間に経験した完全重複腎孟尿管22例の診 断・治療上の諸問題について報告した，診断では腎シ ンチによる腎機能評価と VCU・内視鏡検査による hiatus 分類・瘤外翻の有無の判定が治療方針決定上重 要で, 治療では原則として 1 期的手術・患尿管は可及 的に摘出すべきことを強調した。 また経尿道的尿管瘤 遠位部小切開法の意義についても考察した。

\section{文献}

1）小柳知彦, 辻 一郎: 完全重複腎尿管に伴亏腎尿 路異常；23症例の臨床, 外科的治療及び発生につ いての考察。日泌尿会誌，68，1218-1238，1977.

2）松野 正, 後藤敏明, 小柳知彦: 異所性尿管瘤の外 科治療一hiatus 分類に基づいた strategy一. 日泌 尿会誌，75，1444-1451， 1984.

3) Koyanagi, T., Hisajima, S., Gotoh, T., Tokunaka, S. and Tsuji, I.: Everting ureteroceles: Radiographic and endoscopic observation, and surgical management. J. Urol., 123, 538-543, 1980.

4）小柳知彦, 徳中荘平, 松野 正, 後藤敏明, 辻一 郎：小児異所開口尿管症 40 例の治療経験一特に完 全な異所尿管断端の処置を含めた 1 次的外科治療 法一. 日小外誌, 17, 647-658, 1981.

5) Wickramasinghe, S.F. and Stephens, F.D.: Paraureteral diverticula: Associated renal morphology and embryogenesis. Invest. Urol., 14, 381-385, 1977.

6) Tokunaka, S., Koyanagi, T., Matsuno, T., Gotoh, T. and Tsuji, I.: Paraureteral diverticula: Clinical experience with 17 cases with associated renal dysmorphism. J. Urol., 124, 791-796, 1980.
7) Tortora, F.L. Jr. and Landes, R.: Endoscopic ureteroneocystostomy for orthotopic ureter. oceles. J. Urol., 127, 31-33, 1982.

8) Shapiro, S.R.: Reflux and duplicated ureters. in Management of Vesicoureteric Reflux, Johnston, J.H., 1st ed., chapt. 17, p. 215, Williams \& Wilkins Co., Baltimore/London, 1984.

9）後藤敏明：尿管膀胱接合部先天異常と所属腎の機 能々構造一特に腎形成異常発生々の関係一。日泌 尿会誌，74，1493-1508， 1983.

10) Mackie, G.G. and Stephens, F.D. : Duplex kidneys: A correlation of renal dysplasia with position of the ureteral orifice. J. Urol., 114, 274-280, 1975.

11) Tokunaka, S., Gotoh, T., Koyanagi, T. and Miyabe, N.: Muscle dysplasia in megaureters. J. Urol., 131, 383-390, 1984.

12) Johnston, J.H. and Heal, M.R. : Reflux in complete duplicated ureters in children: Manage ment and techniques. J. Urol., 105, 881-887, 1971.

13) Ogawa, A., Kakizawa, Y. and Akaza, H.: Ectopic ureter passing through the external urethral sphincter: Report of a case. J. Urol., 116, 109-110, 1976.

14) Koyanagi, T., Hisajima, S., Sakashita, S., Gotoh, T. and Tsuji, I.: Ureteral ectopia in vestibule without urinary incontinence. Urology, 16, 508-510, 1980.

15）内山武司，千葉栄一：尿失禁を伴わない胯前庭部 尿管異常開口の 1 例。臨泌，38，251-254， 1984.

16) Brock, W.A. and Kaplan, G.W.: Ectopic ureteroceles in children. J. Urol., 119, 800-803, 1978.

17) Geringer, A.M., Berdon, W.E., Seldin, D.W. and Hensle, T.W.: The diagnostic approach to ectopic ureterocele and the renal duplication complex. J. Urol., 129, 539-542, 1983.

18）島田憲次, 数本秀典, 森 義則, 生駒文彦：異所性 尿管瘤一本邦報告例の統計を含む一，日泌尿会誌， 74, 1003-1014, 1983.

19) Monfort, G., Morrison-Lacombe, G. and Coquet, M. : Endoscopic treatment of ureteroceles revisited. J. Urol., 133, 1031-1033, 1985.

20）後藤敏明, 森田 肇, 徳中荘平, 小柳知彦, 工藤哲 男, 西田 亨：尿管瘤を凝わせた男子単一性異所 開口尿管の 1 例. 臨泌，37，159-163，1983.

21) Stephens, F.D. : Duplex ureters. in Congenital Malformations of the Urinary Tract, 1st ed., chapt. 19, p. 286-306, Praeger Publishers, New York, 1983.

22) Androulakakis, P.A., Ossandon, F. and Ransley, 
P.G. : Intrinsic pathology of the lower moiety ureter in the duplex kidney with ectopic ureterocele. J. Urol., 125, 873-874, 1981.

23) Stephens, F.D.: Caecoureterocele and concepts on the embryology and etiology of ureteroceles. Aust. N. Z. J. Surg., 40, 239-248, 1971.

24) Malek, R.S., Kelalis, P.P., Stickler, G.B. and Burke, E. : Observations on ureteral ectopy in children. J. Urol., 107, 308-313, 1972.

25) Kelalis, P.P.: Ectopic ureterocele. in Clinical Pediatric Urology, Kelalis, P.P., King, L.R. and Belman, A.B., 1st ed., p. 522-535, W.B. Saunders Co., Philadelphia, 1976.

26) Cobb, L.M., Desai, P.G. and Price, S.E.: Surgical management of infantile (ectopic) ureteroceles: Report of a modified approach. J. Pediatr. Surg., 17, 745-748, 1982.

27) Cendron, J., Melin, Y. and Valayer, J. : Simplified treatment of ectopic ureterocele in 35 children. Eur. Urol., 7, 321-323, 1981.

28) Belman, A.B., Filmer, R.B. and King, L.R.: Surgical management of duplication of the collecting system. J. Urol., 112, 316-321, 1974.
29) Culp, O.S.: Heminephroureterectomy: Comparison of one-stage and two-stage operations. J. Urol., 83, 369-375, 1960.

30) Mandell, J., Colodny, A.H., Lebowitz, R., Bauer, S.B. and Retik, A.B.: Ureteroceles in infants and children. J. Urol., 123, 921-926, 1980.

31) Caldamone, A.A., Snyder, H.M. III and Duckett, J.W. : Ureteroceles in children : Follow up of management with upper tract approach. J. Urol., 131, 1130-1132, 1984.

32) Kroovand, R.L. and Perlmutter, A.D.: A onestage surgical approach to ectopic ureterocele. J. Urol., 122, 367-369, 1979.

33) Hendren, W.H. and Mitchell, M.E.: Surgical correction of ureteroceles. J. Urol., 121, 590 $-597,1979$.

34) Amar, A.D.: Ipsilateral ureteroureterostomy for single ureteral disease in patients with ureteral duplicaton: A review of 8 years of experience with 16 patients. J. Urol., 119, $472-475,1978$.

（1985年10月17日受付） 